\title{
Science Teachers and Budget Planning for Instructional Resources in Secondary Schools in Nairobi, Kenya
}

\author{
Charles Richard Oyier ${ }^{1}$, Paul Amollo Odundo ${ }^{1}$, Boniface Ngaruiya $^{1} \&$ John Mwangi $^{1}$ \\ ${ }^{1}$ Department of Educational Communication and Technology, University of Nairobi, Kenya \\ Correspondence: Paul Amollo Odundo, Department of Educational Communication and Technology, University \\ of Nairobi, P. O. Box 30197 - 00100, GPO, Nairobi, Kenya.
}

Received: August 26, 2017

Accepted: October 3, 2017

Online Published: October 17, 2017

doi:10.20849/aes.v2i3.198

URL: https://doi.org/10.20849/aes.v2i3.198

\begin{abstract}
Achieving transformational knowledge based economy as provided for in Kenya's Vision 2030, requires adequately budgeted for science instructional resources. This is because instructional resources are key in practical work which enhances learners experience and understanding science concepts, hence better learning achievement. This study sought to establish the link between budget planning in secondary schools in Nairobi County to their financial management policies in terms of setting up structures for handling budgetary allocations in a coordinated approach through consultation with staff. It relied on a sampled principals and science teachers from public and private schools in Nairobi County obtained using stratified sampling techniques. Using cognitive based participatory decision making model, the study established that secondary schools have budgeting objectives that take science instructional resources in consideration; science teachers place their budgetary request based on their schemes of work to the budgeting committee and are present during prioritization on departmental list. It also established that systems for projecting revenues and expenditures are established in secondary schools to link policy objective on science instructions and resources and that allocations for instructional resources are specified in school budget in public secondary schools than their private counterparts. In practice, the study recommended that science teachers need to be involved in budgetary decision making and measure be put in place to ensure this happen. It suggested more research on the role science teachers in improving learning outcomes through participation in budgetary decision making.
\end{abstract}

Keywords: budget planning, instructional resources, budgeting objectives, budget requests, prioritization in budgeting, budget projections

\section{Introduction}

Globally, governments recognize key role played by science education in building human capital and innovations required for the transition to a knowledge driven economy, hence the need for adequate budgetary allocation for instructional resources. Supporting this position or instance, in a case study of related factor affecting Nigerian secondary school academic performance, Banuso (2003) noted that improved economic forecasting and planning are important in ensuring appropriate budgetary allocation for instructional resources. Kenya's Vision 2030 proposes intensification of science education to raise productivity and efficiency levels across the three pillars of national development; namely economic, social and political (Amunga, Amadalo \& Musera, 2011). Even though Science, Technology and Innovation policy (GoK, 2012) present Kenya government with an implementation framework which focusses on application of relevant scientific knowledge across sectors of the economy, there was a need to investigate budgetary provision put in place for its realization through instruction. Achieving transformational knowledge based economy as provided for in Kenya's Vision 2030, requires adequately budgeted for science instructional resources (Migosi 2015). However, Wanzare (2006) found out that in most cases appropriate, plan to budget for instructional resources is lacking in Kenyan secondary schools.

\subsection{Budget Planning and Instructional Management}

Instructional resources are key in practical work which enhances learners experience and understanding science concepts, hence better learning achievement. In supporting this position Amadalo, Ocholla and Memba, (2012) linked adequately availed and utilized instructional resources in teaching sciences to better learning outcomes. Quality of science education can be enhanced through proper planning for instructional resources. Planning for 
instructional resources demands that money be set aside and budgeted for to make them available and adequate in secondary schools (Hammond, 2007). Supporting this position Validya (2003) asserted that adequate budgetary allocation for instructional resources would ensure good learning outcomes for science subjects. However, good learning outcomes for biology, chemistry and physics would require effective management of budgetary allocation to ensure appropriate utilization of instructional resources in the classroom. Further, Njagi and Jagongo (2013) maintained that effective utilization of instructional resources is key determinant of learning outcomes.

\subsection{Budget Planning and Realization of Learning Outcomes in Sciences}

Realization of good learning outcomes requires adequate budgetary allocations for instructional resources. Budget planning is essential in ensuring adequate budgetary allocation for science instructional resources. As noted by Kruger (2005) budget planning involves setting objectives, determining resources, soliciting requests, determining projections and cost to enhance effective management of school resources. This study acknowledged Kung, Huang and Cheng (2015) assertion from a study in China that budget planning influence organizational management performance. In doing this a comparative link between corporate organizations and secondary schools was established on realization that budget planning would influence instructional management through budgetary allocation. Ideally, measures of performance in science instructional management are learning outcomes and would depend on how appropriately resources are planned for through a budgeting process. It is essential to acknowledge that a planned budgeting process could enhance utilization instructional resources purposely for learners to gain necessary skills and enjoy sciences based disciplines (Oyoo, 2004). As a component of budgeting process budget planning assures adequate allocation for various activities in a secondary school. As argued by Lemelin (2005), through setting objectives, determining resources, soliciting requests, determining projections and cost; budget planning enhances effective management of school resources.

\subsection{Budget Planning in Secondary School}

A school budgeting process starts with a planning phase and results into a mission statement expressed in monetary terms. Budget planning phase, more importantly should result in a statement of intentions geared towards realisation of instructional goals through resources allocation. In support of this position, Cole and Kelly (2011) noted that planning in school budgeting process involves formalization of objectives and then arranging for provision of resources in order to achieve desired instructional outcomes. For desired learning outcomes, the product of budget planning should be a statement of desired activities expressed in financial terms in pursuit of instructional goal over a period of one year. In order to achieve desired learning outcomes in sciences, secondary school leaderships employ various budget planning strategies. These strategies according to Kung, Huang and Cheng (2015) are mediators which are positively influenced by budget planning approaches. For effective utilization of science instructional resources, a collaborative approach involving subject teachers would have significance on learning outcomes in biology, chemistry and physics. Supporting this line of argument, Kung, Huang and Cheng (2015) asserted that stakeholders' involvement was a key consideration in designing budget planning strategies. In investigating the influence of budget planning in utilization of instructional resources, this study considered science teachers as key stakeholders in secondary schools budgetary decision making process

\subsection{Science Teachers and Budget Planning}

Science teachers as suggested by Cole and Kelly (2011) are responsible for budget implementation in instructional management and this study argued that participation of science teachers in budget planning had a significant influence on learning outcomes. Reviewed literature has so far indicated that science learning achievements in secondary schools is influenced by strategic budgetary allocation for instructional resources. In support of this position, Luck (2011) argued that involvement of science teachers in budgetary allocation decisions for instructional resources is a critical element in learning outcomes. This becomes move evident when budgetary allocations results in appropriate utilization of instructional resources in learning sciences. From United Kingdom, Mascitti-Miller (2012) examined practices in budgetary allocation in elementary schools and found out that principals discretionally allocated resources to create a high performing school. This disregards an emerging view from reviewed literature that participation of stakeholders in budget planning have a significance correlation with learning outcomes. Ideally, instructional needs for science subjects are better identified by teachers through the department and forwarded to budgeting committee as part of budget planning in secondary schools. According to Mascitti-Miller (2012), principals should be flexible in their approach in spending in order to strategically meet instructional needs of their schools. However, this study focused on a consultative approach in budget planning in secondary schools. Lemelin (2005) suggested that of science teachers need to participate in setting objectives, resources identification, soliciting requests, determining projections cost in budget planning. 
In acknowledging different positions of Mascitti-Miller (2012) and Lemelin (2005), this study appreciated the fact that budget planning is a dynamic process typically marked by regular phases that requires consultative approach in formulation of objectives, needs assessment and priority setting.

\subsection{Setting Objectives in Budget Planning for Instructional Resources}

Every educational institution ought to have strategic directions regarding instructional management. Strategic direction on instructional management informs setting of budget objectives in line with schools' curriculum goal. Echoing this position, Mulwa (2005) asserted that strategic direction for instructional management is a milestone with clear set of actions on budgetary allocation, sourcing and utilization of teaching and learning resources. Key action plan in instructional management as a milestone is budgetary allocations for teaching and learning resources that would determine their availability and adequacy. Adequate allocation of funds for instructional resources during budget planning starts with setting objectives which links resource management to desired learning outcome in sciences. Moswela (2009) in a study on secondary school development plan in Botswana as an instructional management strategy concluded that budget planning should be informed by curriculum objectives. Borrowing from Moswela (2009), the argument in this study was that curriculum objectives are synonymous with instructional goals in secondary schools strategic direction. This translates into budget objectives is a basis for considerations when funds are being allocated for science instructional resources. In Budget planning process therefore instructional goals are transformed into one of the budgeting objectives purposely to strengthen instructions in secondary schools. The concern of this study was to establish whether secondary schools in Nairobi County take science instructional resources in consideration when setting budgeting objectives.

\subsection{Soliciting Requests in Budget Planning for Instructional Resources}

School budget planning requires budgetary requests to come from departments and sections within the institution. This should be provided for in secondary schools financial management policy which outlines budgetary ceilings for different activities. Supporting this position, Ojiambo (2010) from a study in Bungoma District focussing on public secondary schools recommended that sections and departments should be sending their budgetary requests to budgeting committee. From science department budgetary request should be prioritized to include acquisition of instructional resources necessary for realization of quality learning outcomes. Roza (2009) in an article on school budgeting noted that budgetary requests build on progress on key developments over the past year within departments. Science department budgetary requests would therefore indicate resources required to enhance instructional management in secondary schools purposely to improve learning outcomes. Ideally, through budgetary requests secondary schools are capable of implementing of instructional management goals with the aim of securing a strong future for every student. This is achieved by emphasizing and promoting quality science learning. Clarke (2007) emphasized that budget planning should involve science teachers in coming up with budgetary requests as instructional managers from the departmental level. Further, Roza (2009) noted that improved learning outcomes from science instructions positions learners for success as adults and promotes economic growth and global competitiveness. Therefore budget requests should support continued innovation in instructional management by providing increased resources to scale up new models for teaching and learning. As Wadesango (2011) puts it, scaling up new models for science instructions through budgeting process provides an excellent focus on equity at each level of education system, in every school and in all departments to ensure quality instructions.

\subsection{Prioritization in Budget Planning for Instructional Resources}

Financial management policy in a school is crucial in outlining how use of funds should be prioritized to avoid wastage and misappropriation. Clarke (2007) noted that budgeting should be guided by identifying priorities and this will ensure available institutional financial resources meet budgetary needs in the best way possible for realization of educational gaols. Consequently, channelling resources towards activities which will have the greatest impact toward realization of instructional goals should be the focus of secondary schools budgeting process. This will enable learners to have access to rigorous coursework through appropriate utilization of instructional resources. Secondly, budgeting as development process, prioritization should include assessing initiatives in science department funded in the previous financial year. Representation of science teachers should provide a status update on the progress of all initiatives their area and to what degree they have been accomplished. Further, Florescu (2012) noted that with the knowledge of reasons behind budgetary cutbacks, science teachers would come up proposal to restructure delivery approaches in the classroom while still focusing on the overall schools instructional goal. In general using a common approach to budgeting is not only an across-the-board reduction process, but should result into reviewing instructional approach to maintain focus on favourable learning outcomes in science subjects as priority. For appropriate utilization, science teachers ought 
to be present during prioritization through representation by either head of department or specifically appointed member in secondary schools budgeting committees. This study sought to establish the extent of involvement of science teachers in prioritization during budgeting.

\subsection{Making Projections in Budget Planning for Instructional Resources}

Secondary school budgeting committees hold multiple sessions to deliberate the proposed initiatives from various departments and sections focusing on aligning financial commitment of the projected resources that could be available. Getange, Onkeo and Orodho (2013) in a study on alternative sources for funding for public secondary schools in Kisii County established that secondary schools principals have devised alternative sources of financing education. In such cases, a forecast of projected revenues include alternative sources such as income generating activities, school fees and funding from government's Free Day Secondary Education (FDSE) initiative. Oplatka (2004) in an article on the role of principals in institutional management noted that secondary schools in developing countries have challenges in managing limited revenues due to autocratic leadership style, less open and low degree of change initiation in budgeting for instructional resources. Such kind of leadership makes it difficult task for secondary schools to carry out revenue projection and in turn would negatively affect provision of instructional resources. Echoing this position, Mbugua and Rarieya (2014) asserted that secondary schools leadership should strategically consider involvement of science teachers in revenue and expenditure projects for better learning outcomes in biology, physics and chemistry. However, from reviewed literature no scholarly work has considered the role of teachers in revenue and expenditure projection. Further, no work has been done to establish significance of revenue and expenditure projection during budget planning in secondary schools in Nairobi County towards realization of better learning outcomes in biology, physics and chemistry. This study aimed at establishing how revenue and expenditure projection influence budgetary allocations on utilization of science instructional resources in secondary schools in Nairobi County, Kenya.

\subsection{Budgetary Allocations for Instructional Resources}

Budgetary allocation of funds by budgeting committee should be based on considerations of a combination of programmatic and formulaic approaches linking science instructional management to overall school educational goal. In their work, Ankomah, Koomson, Bosu and Oduro (2005) on implementing quality education in low-income countries suggested that Secondary schools should efficiently and effectively manage budgeting process in order to ensure that available resources are considered for instructional management. However, because of limited and tighter revenue sources for secondary schools budgeting processes, much challenges exist in tying allocations and expenditures to strategic goals. Chetambve and Sakwa (2013) from their study on financial performance of schools in in Trans-Nzoia County, Kenya, recommended that schools' financial management policies should reinforce transparency in budgetary allocation to ensure good learning outcomes. In allocating funds for science instructions it is prudent to specifying what has been given per subject per class as requested by science department. Supporting Chetambve and Sakwa (2013) recommendation, Gachithi (2010) suggested the need for proper procedures and guidelines in the allocation of funds to ensure instructional goals are realized. However, both studies (Chetambve \& Sakwa, 2013; Gachithi, 2010) did not consider budgetary allocation per subject per class. Delineation of budgetary allocations for science instructional resources per each of the three subjects per class will improve utilization and positively influence learning outcomes. This would be in tandem with recommendation made in study in Nigeria on financial management of public secondary schools by Adeogun (2001) which proposed that each lesson should adequately be taught with appropriate instructional resources. This study focussed on establishing if budgetary allocations for science instructional resources are delineated per subject per class in secondary schools in Nairobi County, Kenya.

\section{Statement of the Problem}

Conformity to budget planning procedures and guidelines as noted by Banuso (2003) would ensure delineated budgetary allocations for sourcing of instructional resources in secondary schools. Availability of appropriate instructional resources in each science lesson will automatically improve biology, chemistry and physics instruction in secondary schools. Studies have indicated that budget planning could contribute constructively towards enabling instructional programmes implementation in secondary school. However, there is no scholarly work that have linked involvement of science teachers and adequate budgetary allocations for instructional resources. Therefore it was necessary to establish the extent to which involvement of science teachers in budget planning as an input towards realization of quality learning outcomes in secondary schools. Specifically, it was key establish the link between budget planning in secondary schools in Nairobi County to their financial management policies in terms of setting up structures for handling budgetary allocations in a coordinated approach through consultation with staff. This was investigated in respect to setting budget objectives, drawing 
instructional resources requests for inclusion into the budget; playing a role in prioritization stage, revenue and expenditure projections to ensure fare budgetary allocations for instructional resources.

\section{Purpose of the Study}

The purpose of this study was to establish the role of science teachers' budget planning in setting budget objectives, in drawing instructional resources requests for inclusion into the budget; in playing a role in prioritization stage, revenue and expenditure projections to ensure fare budgetary allocations for instructional resources.

\subsection{Study Objectives}

a. To establish the role of science teachers' in setting objectives during budget planning in secondary schools.

b. To establish the role of science teachers' in determining resources during budget planning in secondary schools.

c. To establish the role of science teachers' in soliciting requests during budget planning in secondary schools.

d. To establish the role of science teachers' determining projections and cost during budget planning in secondary schools.

\section{Theoretical Framework}

This study adopted cognitive based participatory decision making model. This model suggests considers participatory decision making as a strategy in enhancing information flow and use as key elements in organizational management. In secondary schools' organizational structure free information flows strengthens relationship between teachers and principals thereby enhancing participatory decision making. According to Somech (2010) cognitive participatory decision making model acknowledges teachers' knowledge in instructional management and their participation budget planning would be enhanced through an effective information handling system. Echoing these sentiment, this study considered science teachers participation in decision making leading budgetary allocation for instructional resources as a means to principals to access key information necessary for improving learning outcomes. As noted by Hussien (2015), enhanced access information is vital towards improvement of instructional management decisions making through budget planning in secondary schools. Further, cognitive participatory decision making models suggest that participation of science teachers in budget planning will make curriculum implementation more procedural resulting in good learning outcomes. Ideally, participation of science teachers in budgetary decision making will make them discover new pedagogical challenges and opportunities in science instructions. This in turn would promote and foster informed exchange among teachers and secondary school principals.

\section{Conceptual Framework}

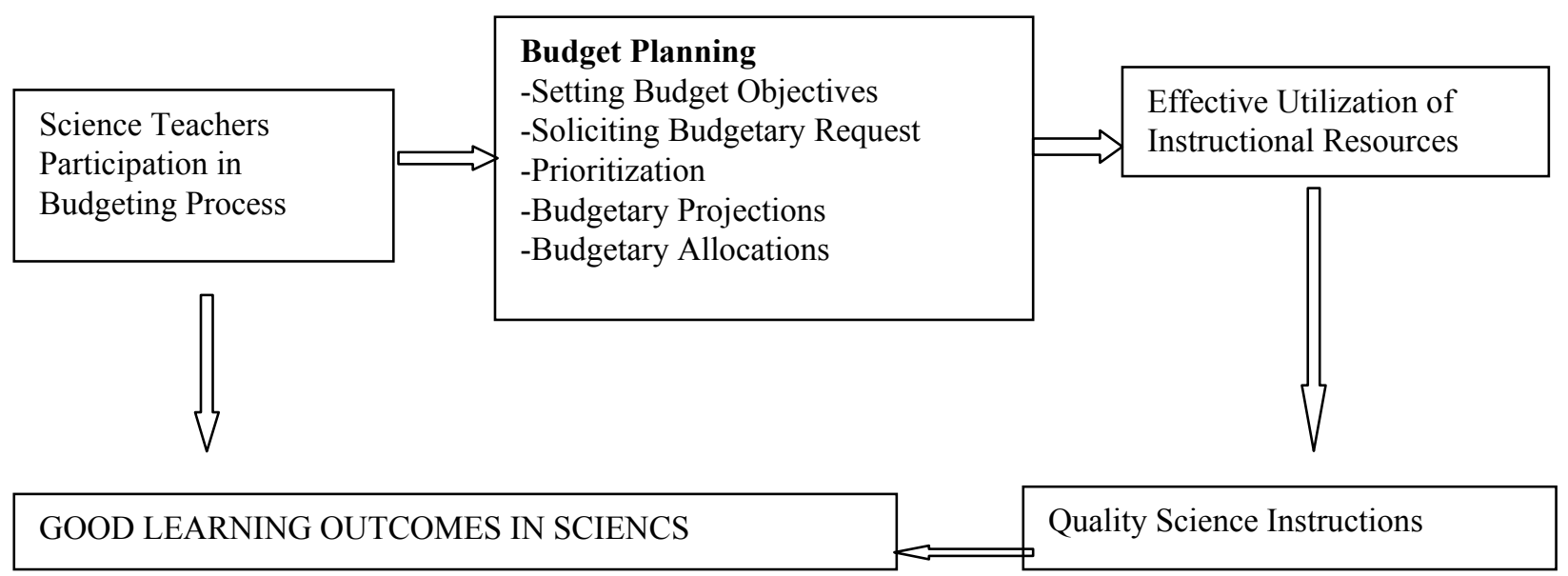




\section{Methodology}

The research design used was descriptive survey in questionnaires were used to obtain quantitative data, which was used to generate frequency distributions and percentages from the school and personal background information. The study relied science teachers from 33 public and private schools in Nairobi County obtained using stratified sampling techniques. From selected schools, three science teachers were purposely sampled because there role in instructional management. Data was obtained from 83 out of 99 sampled science teachers and was analysed using SPSS version 23 and tabulated using descriptive statistics

\section{Findings and Discussions}

\subsection{Characteristics of Science Teachers}

In Kenya science teachers licensed to teach in secondary schools according Teachers Service Commission (TSC) should possess diploma or a degree in education to teach either biology, chemistry or physics. Such qualifications and the institutions they are obtained from should be recognized by the Commission of Higher Education (CHE). This study obtained information from one science teacher for each of the three subjects from the sampled schools who filled questionnaires. In total 83 science teachers participated in this study and analysis of data on their characteristics presented in Table 1.

Table 1. Characteristics of Science Teachers

\begin{tabular}{llcc}
\hline Variable & & Frequency & Percentage \\
\hline Gender & Male & 39 & $47.00 \%$ \\
& Female & 44 & $53.00 \%$ \\
Qualifications & Graduate & 75 & $90.50 \%$ \\
& Post-Graduate & 8 & $9.50 \%$ \\
\multirow{3}{*}{ Age } & 30 years and below & 4 & $4.50 \%$ \\
& 31-40 years & 40 & $48.20 \%$ \\
& 41-50 years & 28 & $33.70 \%$ \\
& Over 50 years & 11 & $13.30 \%$ \\
\hline
\end{tabular}

A total of 83 science teachers filled questionnaires and in Table 1 it is shown that 44(53.00\%) were females while $39(47.00 \%)$ were males. This was an indication that nearly an equal number of female and male science teachers teach chemistry, biology and physics in Nairobi county secondary schools. These findings are in tandem with De Grauwe et al (2011) assertion that teachers' participation in budgetary decision making on funds allocations for instructional resources is key and disregards gender. Secondly, the fact that there is equal representation of both genders in teaching of sciences echoes Burusic, Babarovic and Seric (2012) argument that effects interaction of teachers' and learners' gender on learning outcomes are insignificant. Science teachers' professional training is a factor as far as planning for instructions are concerned. From this study, it was established that all science teachers were graduates with $8(9.50 \%)$ of them having post-graduate qualifications. As noted by Okorie (2001), this level of training provided required competence in not only in planning but also in utilization of instructional resources by science teachers. Given, Kenyan educational system science teachers with undergraduate degrees join the profession at an average age of 25 years (Yala \& Wanjohi, 2011). According to Table 1, 40(48.20\%) out of 83 science teachers were aged between 31-40 years old, meaning they already had 5 to 15 years of experience and having required competency in budget planning for instructional resources. Another, 28(33.70\%) were 41-50years old while $11(13.30 \%)$ were 50years old and only $4(4.50 \%)$ were below $30 y e a r s$ of age. These findings indicated in Nairobi County science teachers had experience and competency to participate effectively in decision making leading to budgetary allocations for instructional resources. This was in line with Song, Hans van der Bij and Mathieu (2005) assertion that learning outcomes are positive correlated to teacher experiences. Ideally this study findings concurred with Somech (2002) that experience of 5 years is adequate for effective participation in managerial decision making.

\subsection{Budget Planning Process}

Budget planning ensures that adequate allocation for instructional resources for effective science learning in secondary schools. In carrying out budget planning, secondary schools need to have a budget preparation 
timetable setting process in clearly defined stages to be undertaken to ensure adequate and balanced budgetary allocations are done (Kruger, 2005). Ideally, planning of school finances is a dynamic process that should be marked by regular stages ending up with balanced budget. According Lemelin (2005), budget planning involves setting objectives, determining resources, soliciting requests, determining projections and cost to enhance effective management of school resources to realize educational goals. In agreements with both Lemelin (2005) and Kruger (2005) this study summarized that budget planning starts with setting objectives through, soliciting requests, prioritization, projections and ends with actual budgetary allocations and the responses from science teachers on them are provided in Table 2. In this study, science teachers were asked to indicate on a five-likert scale the extent to which a number of issues correctly describe budgeting process in their school (where 1= strongly disagree, $2=$ Disagree, $3=$ Uncertain, $4=$ Agree and 5= Strongly Disagree). The descriptive statistic presented in tables in this section was interpreted using means to indicate score for budgeting process practices. A mean score of below 3 implies disagreement that budgeting process aspects to which it applies is not practiced in budgeting for instructional resources by secondary schools in Nairobi County studied. Meanwhile a mean score of above implied that secondary schools studied practice the budgeting process aspect and embraces it

Table 2. Results on Teachers Response on Budget Planning

\begin{tabular}{lccc}
\hline Descriptive Statistics & N & Mean & Std. Dev \\
\hline Budgeting objectives take science instructional resources in consideration & 83 & 3.43 & .413 \\
$\begin{array}{l}\text { Science teachers place their budgetary request based on their schemes of work } \\
\begin{array}{l}\text { Science teachers meet at departmental to list instructional resources priorities } \\
\text { to be included in the budget. }\end{array}\end{array}$ & 83 & 3.31 & .510 \\
$\begin{array}{l}\text { System for projecting revenues/expenditures established to link policy } \\
\text { objective on science instructions and resources. }\end{array}$ & 83 & 3.36 & .491 \\
\begin{tabular}{l} 
Allocations for science instructional resources are delineated in School Budget \\
\hline
\end{tabular} & 83 & 3.33 & .501 \\
\hline
\end{tabular}

\subsection{Setting Objective}

Strategic considerations in financial management influence the way money is allocated at in secondary schools to enable realization of instructional goals. These strategic considerations should be formulated into objectives to define how resource in school systems are best be distributed, utilised and managed to optimise outputs, encourage successful instructional management and promote continuous improvement (Cole \& Kelly, 2011). This study sought from science teachers' possibilities of secondary schools in Nairobi County having formulated budgeting objectives that take science instructional resources in consideration. According to Table 2, the response from science teachers gave a mean of 3.43 with a standard deviation of 0.413 , an indication that secondary schools in Nairobi County having formulated budgeting objectives that take science instructional resources in consideration. The study findings concurred with Clarke (2007) assertion that budgeting for instructional resources should be guided by the school's vision from clearly defined objectives are drawn. However, a standard deviation of 0.413 show dispersion in findings from science teachers and meant that in some secondary schools budget planning proceeds without objectives to guide resources allocation towards desired instructional outcomes. Without adequately written budgeting objective to guide instructional management there is a likelihood of undesirable learning outcomes in science subjects. Variation in science teachers' responses on budgeting objectives could be a factor of leadership style in secondary schools. This would ultimately influence instructional management in secondary schools through adequate resource allocations. Further analysis was presented in Table 3

Table 3. Science Teachers and Budgeting Objectives

\begin{tabular}{lcccc}
\hline School category & Disagree & Uncertain & Agree & Total \\
\hline National & 0 & 2 & 4 & $\mathbf{6}$ \\
County & 4 & 15 & 22 & $\mathbf{4 1}$ \\
Private & 8 & 12 & 16 & $\mathbf{3 6}$ \\
Total & $\mathbf{1 2 ( 1 4 . 4 \% )}$ & $\mathbf{2 9}(35.4 \%)$ & $\mathbf{4 2 ( 5 0 . 6 \% )}$ & $\mathbf{8 3}$ \\
\hline
\end{tabular}


Findings in Table 3, indicated that majority of 50.6\% (42) of science teachers agreed that secondary schools in Nairobi County have budgeting objectives that take in consideration science instructional resources. The other half of science teachers in secondary schools in Nairobi County were either uncertain, disagreed or strongly disagreed. This can be attributed to decision making approach in secondary schools which defines strategic engagement on budgeting process for science instructional resources. It also showed that in some secondary schools there is a more inclusive and participatory approach as noted by Reeves (2008) in linking strategic planning and financial management policy for the purpose of enhancing utilization of science instructional resources. Further, Table 3 also showed variation of science teachers' responses in terms of secondary schools category. Out of six science teachers from national secondary schools four agreed and two were uncertain of existence of budgeting objectives in their institutions. From county secondary schools 22 science teachers agreed, 15 were uncertain and four disagreed. From private secondary schools 16 science teachers agreed, 12 were uncertain and eight disagreed. These results were more varied and an indication that in public secondary schools were more likely to have budgeting objectives that guide resources allocations as far science instruction was concerned than in their private counterparts. It also suggest that some secondary schools in Nairobi County could be concentrating more on physical resources ignoring instructional resources (Rumelt, 2011)

\subsection{Soliciting Requests}

During budget planning requests should come from all departments and sections within secondary school. This should generally takes the form of written communication, but could be a presentation to the budgeting committee at one of its meetings (Ojiambo, 2010). This study sought to establish whether science teachers base their budgetary request schemes of work. The findings gave a mean of 3.31 with a standard deviation of 0.510 according to Table 2. This is an indication that in secondary schools within Nairobi County budgetary request from science teachers were based on each subject schemes of work. It further suggest that in secondary schools in Nairobi County science teachers consolidates their budgetary requests at departmental meeting where required instructional resources are extracted from the schemes of work. These findings underscored the role of departments in ensuring quality instructions and overall learning achievements. However, the extent to which science teachers put their budgetary requests for instructional resources through departmental meetings depends on secondary schools financial management policy (Hussien, 2015). For this reason variation of responses by science teachers was expected as presented in Table 4.

Table 4. Science Teachers and Soliciting Budgetary Requests

\begin{tabular}{lcccc}
\hline School category & Disagree & Uncertain & Agree & Total \\
\hline National & 2 & 3 & 1 & $\mathbf{6}$ \\
County & 7 & 9 & 25 & 41 \\
Private & 9 & 13 & 14 & $\mathbf{3 6}$ \\
Total & $\mathbf{1 8}(\mathbf{2 1 . 7 \% )}$ & $\mathbf{2 5 ( 3 0 . 1 \% )}$ & $\mathbf{4 0}(\mathbf{4 8 . 2 \% )}$ & $\mathbf{8 3}$ \\
\hline
\end{tabular}

Findings in Table 4, indicates that out of 83 science teachers $48.2 \%$ (40) agreed that they normally place their budgetary request based on their schemes of work. Secondly, 30.10\% (25) of science teachers were uncertain and $21.7 \%$ (18) disagreed. The fact that slightly more than half of science teachers were uncertain or disagreed was an indication that schemes of work were written and submitted either to the head of science department or to the principal and beyond that science teachers do not know what happens in secondary schools in Nairobi County. This suggests that secondary schools principals hide issues from teachers as far as financial management is concerned. These findings therefore echoes Kipkoech and Chesire (2011), assertion that teachers in secondary schools managerial abilities remain unrecognized and unmet merely because principals take up most of the managerial decisions. In terms of science teachers' responses based on categories of their institutions, Table 4 showed that out of six science teachers from national's secondary schools only one agreed that budgetary request are based on schemes of work, 3 were uncertain and two disagreed. From county secondary schools, out of 41 county schools science teachers, 25 agreed, nine were uncertain and seven disagreed. From private secondary schools, out of 36 science teachers, 14 agreed, 13 were uncertain and nine disagreed. This suggests that most science teachers in county secondary schools base their budgetary request on schemes of work as compared to their counterparts in private schools. These findings concurs Wanzare (2006) that most private schools do not appropriately consider instructional resources during budgeting process. 


\subsection{Prioritization}

Financial management policy in a school is crucial in outlining not only sources of funds required, but also a prioritization system to avoid wastage and misappropriation. To realize this, Clarke (2007), suggested that budgeting process need to be guided by identifying priorities. The reason for this is that institutional financing availability might not meet all its budgetary requirements needed to achieve instructional gaols. Prioritisation in instructional management should involve science teachers in decisions on appropriate instructional resources that must be availed for the best possible learning outcomes. In seeking to participation of science teachers during budgeting committee meeting when prioritization on list of instructional resources to be included in the budget, finding presented in Table 2 gave a mean of 3.36 and standard deviation of 0.491 . A mean of 3.36 was an indication that science teachers in secondary schools in Nairobi County are represented during budgeting committee meeting when prioritization on departmental list of instructional resources to be included in the budget. This echoed Walter (2009) assertion that involvement of science teachers during prioritization leads to efficient and effective utilization of instructional resources Meanwhile standard deviation of 0.491 was an indication of variation in science teachers' responses on their representation during prioritization in budgeting committee. This suggested that in as much as involvement of science teachers during prioritisation is vital in ensuring appropriate science utilization instructional resources, it may not be so in all schools as shown in Table 5.

Table 5. Science Teachers and Budget Prioritization

\begin{tabular}{lcccc}
\hline School category & Disagree & Uncertain & Agree & Total \\
\hline National & 1 & 3 & 2 & $\mathbf{6}$ \\
County & 7 & 12 & 22 & $\mathbf{4 1}$ \\
Private & 7 & 16 & 13 & $\mathbf{3 6}$ \\
Total & $\mathbf{1 5 ( 1 8 . 1 0 \% )}$ & $\mathbf{3 1 ( 3 7 . 3 0 \% )}$ & $\mathbf{3 7 ( 4 4 . 5 \% )}$ & $\mathbf{8 3}$ \\
\hline
\end{tabular}

Findings in Table 5 indicates that out of 83 science teachers, 44.4\%(37) agreed, 37.30\% (31) were uncertain and $18.10 \%$ (15) disagreed that they were represented in budgeting committee during prioritization on instructional resources list. Given that more than half of science teachers who responded either were uncertain or disagreed is an indication of big variation in their responses. Representation of science teachers in budging committee enables them to understand different budgetary trade-offs that would require review of instructional resources requirement to ensure appropriate utilization. However, as already mentioned this was not true in all secondary schools in Nairobi County because the level of involvement of science teachers in prioritization varies. For example, Table 28 showed that out of six science teachers from national secondary schools, only two agreed; from county secondary schools out of 41 science teachers, 22 agreed; while from private secondary schools, out of 36 science teachers three agreed. This suggested that science teachers in county secondary schools were more likely to be represented during prioritization than both national and private counterparts. However, as suggested by Wadesango (2011) representation in budgeting committee is determined by financial leadership approach of an institution.

\subsection{Revenue and Expenditure Projection}

Given their complex and dynamic nature, extensive sources of revenue, and multiple items of expense, secondary schools must have a strategy to efficiently manage resources to achieve instructional goals. This study sought to establish through science teachers the existence of projecting revenues and expenditures system that to link financial policy objective of instructional resources. The responses obtained gave a mean of 3.46 and a standard deviation of 0.501. A mean of 3.46 was an indication that secondary schools in Nairobi County have a system for projecting revenues and expenditures that link financial policy objective to science instructional resources. Ideally, it suggested that secondary schools in Nairobi County had revenues and expenditures projection system that link financial management policy objective to science instructional resources. However, with a standard deviation of 0.501 , the findings show variation in science teachers' responses as illustrated in Table 6. 
Table 6. Science Teachers and Budgetary Projections

\begin{tabular}{lcccc}
\hline School category & Disagree & Uncertain & Agree & Total \\
\hline National & 0 & 2 & 4 & $\mathbf{6}$ \\
County & 2 & 20 & 19 & $\mathbf{4 1}$ \\
Private & 6 & 12 & 18 & $\mathbf{3 6}$ \\
Total & $\mathbf{8 ( 9 . 6 \% )}$ & $\mathbf{3 4}(\mathbf{4 1 . 0 0 \% )}$ & $\mathbf{4 1 ( 4 9 . 4 \% )}$ & $\mathbf{8 3}$ \\
\hline
\end{tabular}

Findings in Table 6 indicate that $49.4 \%$ (41) of science teachers agreed, $41.00 \%$ (34) were uncertain and 9.6\% (8) disagreed. This was an indication that half of secondary schools in Nairobi County had a system for projecting revenues and expenditures that links financial management policy objective to science instructional resources. The fact that half of the science teachers were either uncertain or disagreed suggested that in some secondary schools, financial leadership are less open and lacking focus as far as instructional management is concerned (Drah, 2011). Further, Table 29 showed that out of six science teachers from national secondary schools, four agreed; from county category, out of 41, 19 agreed, while from private category 18 agreed out of 36 that a system for revenue and expenditure projection exist in their institutions. These findings confirmed that about half of science teachers in Nairobi county secondary schools acknowledged existence of a system of revenue and expenditure projection that link policy objective to budgetary allocation for instructional resources. This concurred with Codrington (2004) assertion that adoption of strategic projections influences budgetary.

\subsection{Budgetary Allocations}

There is pressure on secondary schools to efficiently and effectively manage budgeting process in order to ensure effective instructional management while responding to other demand for limited resources. This pressure does not make it easy for budgeting processes to tie allocations and expenditures to strategic goals as earlier noted by (Mulwa, 2005). In allocating funds the budgeting committee should base their considerations by specifying what has been given per activities as requested by various sections and departments. This study sought to establish if allocations for instructional resources are specified in secondary school budget. As presented in Table 2 the findings reveal a mean of 3.33 and standard deviation of 0.483 . These findings indicate that allocations for science instructional resources are specified for each three subjects as requested by science department in secondary schools in Nairobi County. It is also an indication that there is conformity to budget planning procedures and guidelines which according to Banuso (2003) would ensure specified budgetary allocations for science instructional resources. However, a standard deviation of 0.483 was an indication that as much as budgetary allocations is done per subject, it could not be in all among secondary schools in Nairobi County. Further analysis revealed variation of responses from science teachers on budgetary allocations as in Table 7.

Table 7. Science Teachers and Budgetary Allocations

\begin{tabular}{lcccc}
\hline School category & Disagree & Uncertain & Agree & Total \\
\hline National & 2 & 2 & 2 & $\mathbf{6}$ \\
County & 9 & 10 & 22 & $\mathbf{4 1}$ \\
Private & 1 & 21 & 14 & $\mathbf{3 6}$ \\
Total & $\mathbf{1 2}(\mathbf{1 4 . 4 \% )}$ & $\mathbf{3 3}(\mathbf{3 9 . 8 \% )}$ & $\mathbf{3 8}(\mathbf{4 5 . 8 \% )}$ & $\mathbf{8 3}$ \\
\hline
\end{tabular}

Findings in Table 7 shows that $45.8 \%$ (38) of science teachers strongly agreed, $39.80 \%$ (33) were uncertain, $14.4 \%$ (12) disagreed that allocation for science instructional resources are specified in budgets of secondary schools in Nairobi County. As much as the mean of 3.33 in Table 25 indicated delineation of allocation for instructional resources in budgets of secondary schools more than half of science teachers either were uncertain, disagreed or strongly disagreed. The fact that majority of science teachers were either uncertain or disagreed could be attributed to lack of information as suggested by Chetambve and Sakwa (2013) that secondary schools lack transparency in financial issue. Lack of information on budgetary allocations in secondary schools in Nairobi County confirms position held in Transparency International (2010) integrity report on Kenyan education sector which indicated that there is limited disclosure regarding finances for effective instructional management in 
secondary schools. It also echoes Mestry (2006) who reported that teachers have varied perceptions as far as how school principals manage their funds for the purposes of making instructional resources because of lack of adequate information from management. Varied perceptions of science teachers on budgetary allocation for science instructional resources in secondary schools is evidently presented in Table 30. It was shown in Table 4.26 that out of 6 science teachers from national secondary schools, two agreed, two were uncertain and two disagreed that schools budgets allocations for instructional resources are delineated. In county category, out of 41 science teachers in county secondary schools 22 agreed, 10 were uncertain and nine disagreed. From private category out of 36 science teachers 14 agreed, 21 were uncertain and one disagreed. These findings indicate that financial budgets in most county secondary schools have allocations for instructional resources specified and that there was more uncertainty among science teachers from private secondary on specified. High uncertainty among science teachers from private schools can be as result of less government control (Wango \& Gatere, 2013).

\section{Conclusion}

Planning for science instruction starts decision on what to teach, the desired methodology, and appropriate instructional resources. Appropriate instructional resources should be approved at the departmental level then forwarded for budget consideration. Budgeting for instructional resources involves setting objectives, determining resources, soliciting requests, determining projections and cost. To enhance science instructional management at secondary schools level, planning phase of budgeting process should result in a mission statement expressed in monetary terms. This need to be a statement of resources matched to intentions geared towards realization of instructional goals. Science teachers would be critical in budget planning through formalization of objectives which are then expressed in financial terms for desired instructional activities in pursuit of educational goal over a period of one year. Realization of educational goals in terms of learning outcomes requires adequate budgetary allocations for instructional resources. Measures of attainment of educational goals through performance in science instructional management are learning outcomes and would depend on how appropriately resources are planned for through a budgeting process. The best strategy to improve learning outcomes is to involve science teachers in decision making involving budgetary allocations for instructional resources. Therefore if secondary school leaderships should employ budget planning strategies that appreciate the role of science teachers for realization of good learning outcomes. Such strategies should positively influence budget planning approaches that link financial leadership with instructional management. Science teachers' involvement is a key consideration in designing budget planning strategies. This is because they are also responsible for budget implementation as far as instructional management is concerned. It therefore follows that participation of science teachers in budget planning has a significant influence on learning outcomes. The findings of this study have ascertained that science learning achievements in secondary schools could be influenced by strategic budgetary allocation for instructional resources. In this regard decision leadings into budgetary allocation for instructional resources and the effectiveness of their use remains a critical and requires active participation of teachers in setting objectives, determining resources, soliciting requests, determining projections and cost. It requires the discretion of secondary schools principals come up with planning approaches that would enhance best practices in budgetary allocation in order to create a high performing institutions. In conclusion, instructional needs for science subjects are better identified by the teachers through the department and forwarded to school budgeting committee as part of budget planning. In involving teachers provides principals with an opportunity to tailor instructional needs of their school more strategically through a consultative approach in budget planning

\section{Recommendations}

In practice, the study recommended that science teachers need to be involve in decision making and especially on instructional management related process from strategic planning to budgetary decisions. On policy the study recommended that measure should be place for secondary school principals to decentralize budgetary decision making through delegation to departments in effort to improve instructional management. Finally, the study recommended more research on the role science teachers in improving learning outcomes through participation in budgetary decision making.

\section{References}

Adeogun, A. A. (2001). The principal and the financial management of public secondary schools in Osun State. Journal of Educational System and Development, 5(1).

Amadalo, M. M., Ocholla, A. A., \& Memba, E. B. (2012). Effect of Practical Work in Physics on Girls' Performance, Attitude Change and Skills Acquisition in the Form - two three Secondary Schools' Transition in Kenya. International Journal of Humanities and Social Science, 2(23). 
Amunga, J. K., Amadalo, M. M., \& Musera G. (2011b). Disparities in Chemistry and Biology Achievement in Secondary schools: Implications for Vision 2030. International Journal of Humanities and Social Science, l(18), 226-236.

Ankomah, Y., Koomson, J., Bosu, R., \& Oduro, G. K. T. (2005). Implementing Quality Education in Low-Income Countries (Edqual). University of Cape Coast, Ghana.

Banuso, L. A. (2003). A case study of school related factor affecting Nigerian secondary school students' academic performance. Unpublished M. Ed dissertation in Educational Management, University of Ilorin.

Burusic, J., Babarovic, T., \& Seric, M. (2012). Differences in elementary school achievement between girls and boys: Does the teacher gender play a role?. European Journal of Psychology of Education, 27(4), 523-538.

Chetambve, H. N., \& Sakwa, M. (2013). Effects of Financial Training on Financial Performance of Schools in Kenya: A Survey of Administrators of Secondary Schools in Trans-Nzoia County. International Journal of Academic Research in Business and Social Sciences, 3(10), 214-220.

Clarke, A. (2007). The Handbook of School Management. Cape Town: Kate McCallum.

Codrington, S. (2004). Applying the Concept of "Best Practice" to International Schools. Journal of Research in International Education, 3(2), 173-188.

Cole, G. A., \& Kelly, P. (2011). Management: Theory and Practice 7th Edition UK. Cengage learning EMEA Context Rooted in Participatory Strategic Planning, Zapf Chancery and P. Olivex.

De Grauwe, Anton, Candy Lugaz, Tiberius Barasa, Pulane, J. Lefoka, MathaboTsepa, Samuel Kayabwe, \& Wilson Asiimwe. (2011). Strengthening Local Actors: The Path to Decentralizing Education, Kenya, Uganda, and Lesotho, Paris: IIEP and UNESCO.

Drah, S. T. (2011). Teachers' participation in decision making process in senior high and technical Schools in the Kwaebibirem district in the eastern region of Ghana. M.A. Thesis, University of Cape Coast.

Florescu, D. (2012). Management of projects with European Financing, Ed. C N Beck.

Fouche, C. B., \& Delpoort, C. S. L. (2005). Introduction to research process. In de Vos A S et al (Eds.), Research at grassroots: For social science and human service professions. Pretoria: Van Schaik.

Gachithi, E.W. (2010). The challenges of budget implementation in public institutions: a case study of University of Nairobi. Unpublished Thesis, University of Nairobi.

Getange, K. N., Onkeo, J. M., \& Orodho, J. A. (2013). Alternative Sources of Funding For Free Day Secondary Education (FDSE) in Public Schools in Kisii Central District, Kisii County, Kenya. IOSR Journal of Dental and Medical Sciences, 13(4), 14-23.

Hammond, L. (2007). Educational Leadership: A Bridge to School Reform. A Paper Presented at the Wallace Foundation Conference.

Hussein. (2015). Teachers' Participation in School Decision Making In Secondary Schools of Arsi Zone. MA. Thesis. Haramaya University, Haramaya.

Kipkoech, L. C., \& Chesire, S. (2011). The Levels of Teachers' Involvement in Managerial Decision Making in Schools in Kenya. Problems of education in the 21st century, 34, 79-87.

Kruger A. G. (2003). Efficient Financial Management in Van Deventer I \& Kruger A G Ed. An Educator's guide to School Management Skills Pretoria: Van Schaik.

Kung, F., Huang,C., \& Cheng, C. (2015). An Examination of the Relationships among Budget Emphasis, Budget Planning Models and Performance. Management Decision.

Lemelin, C. (2005). Thoughts on Funding Post-Secondary Education. Higher Education in Canada, edited by Charles M. Meach et al. Kingston: McGill-Queens's.

Luck, Tan Lee. (2011). School Principals' Effectiveness and Leadership Quality in Educational Management. Johor: MARA University of Technology.

Makhubela, B. S. (2005). The Role of the School Governing Body in Financial Administration at Sokisi Secondary School: A case study Mini dissertation for Masters in Education University of Pretoria: Pretoria March 21, p. 5.

Mascitti-Miller E. (2012). Resource Allocation: Practices in Urban Elementary Schools. Fisher Digital Publications.

Mbugua, F., \& Rarieya, J. (2014). Collaborative Strategic Planning: Myth or Reality?. Educational Management Administration and Leadership, 42(1), 99-111. 
Mestry, R. (2006). Financial Accountability: The Principal or the school governing body in South African. Journal of Education, 24, 126-134.

Migosi, F. (2015). The Challenges of using Information Communication Technology in School Administration in Kenya. Moi University.

Mulwa, F.W. (2008). Participatory Monitoring and Evaluation of community projects, Nairobi: Pauline.

Njagi, G. N., \& Jagongo A. (2013). Capital Budgeting Procedures and Practices in Public Secondary Schools in Kenya. (The Case Study of Meru North District).

Ojiambo, J. N. (2010). Influence of financial management on quality of education in public secondary schools in Bungoma District, Kenya. Unpublished Thesis, UON.

Okorie, J.U. (2001). Vocational Industrial Educational; League of Researchers in Nigeria (LRN) Bauchi.

Oplatka, I. (2004). The Principalship in Developing Countries: Context, Characteristics and Reality. Comparative Education, 40(3), 427-448.

Oyoo, S. O. (2009). Beyond General Proficiency in Language of Instruction: Towards The Appropriate Perspective on Language for Effective Learning in African Science Classrooms. In M. Shafer and C. MacNamara (Eds.), Proceedings of the $17^{\text {th }}$ Annual Conference of the Southern African Association for Research in Mathematics, Science and Technology Education (SAARMSTE 2009), 19 - 22 January 2009, Rhodes University, Republic of South Africa, pp. 197 - 212. Volume I (Long Papers) Book Version.

Punch, K.F. (2009). Introduction to research methods in education. London: Sage.

Reeves, D.B. (2008). Leading to Change/Making Strategic Planning Work. Educational Leadership Journal, 65(4), 86-97.

Roza, M. (2009). Breaking down school budgets. Education Next, 9(3). Retrieved from http://educationnext.org/breaking-down-school-budgets-2/

Rumelt, R. P. (2011). Good Strategy Bad Strategy: The Difference and why it Matters. New York: Crown Business.

Somech, A. (2002). Explicating the complexity of participative management: an investigation of multiple dimensions. Educational Administration Quarterly, 38(3), 341-371.

Somech, A. (2010). Participative decision making in schools: A mediation moderating analytical framework for understanding school and teachers outcomes. Educational Administration Quarterly, 12, 78-96.

Song, M., Hans vander Bij, \& Mathieu W. (2005). Determinants of the Level of Knowledge Application: A Knowledge- Based and Information-Processing Perspective.

Transparency International. (2010). The Kenya Education Sector Integrity Study Report, 2010. Nairobi: Transparency International. UNESCO (2015). Annual Report 2015.

Validya, N. (2003). Science Teaching for 21st Century. New Delhi: Deep \& Deep Publication PVT. Ltd.

Wadesango, N. (2011). Strategies of teacher participation in decision making in schools. Journal of Social Science, 27(2), 85-91.

Walter, K. E. (2009). Making Good Choices: Sustainable School Improvement. Portland, OR: Northwest Regional Educational Laboratory.

Wango, G. M., \& Gatere, A. W. (2013). Leadership Professional Development Through Integrity and Financial Accountability: Curbing Fraudulent Practices in Schools. Nairobi: Kenya Education Management Institute.

Wanzare, Z. O. (2006). Rethinking School Inspection in the Third World. The Case of Kenya. Retrieved June 21, 2014, from http:www.ualberta.ca.ckreberpaperszak.utm

Yala, P. O., \& Wanjohi, W. C. (2011). Performance Determinants of KCSE in Mathematics in Secondary Schools in Nyamira Division, Kenya. Asian Social Science, 7(20), 107-112.

\section{Copyrights}

Copyright for this article is retained by the author(s), with first publication rights granted to the journal.

This is an open-access article distributed under the terms and conditions of the Creative Commons Attribution license (http://creativecommons.org/licenses/by/4.0/). 